\title{
RESISTENSI TANAMAN KARET KLON IRR SERI 300 TERHADAP PENYAKIT GUGUR DAUN CORYNESPORA
}

\author{
Resistance of the IRR Series 300 Rubber Clones to Corynespora Leaf Fall Disease
}

Alchemi Putri Juliantika KUSDIANA*, Afdholiatus SYAFAAH, dan Fetrina OKTAVIA

Balai Penelitian Sembawa, Pusat Penelitian Karet

Jalan Raya Palembang - Pangkalan Balai KM 29,

PO BOX 1127 Palembang 30001 Sumatera Selatan

*Email : alchemiputri@yahoo.com

Diterima : 4 Januari 2018 / Disetujui : 19 Februari 2018

\begin{abstract}
Corynespora leaf fall disease that is caused by a Corynespora cassiicola (C. cassiicola) fungus is one of the important leaf fall diseases that can cause a decrease of latex production in rubber plantations. One of the important stages to release the new rubber clones are identification of the secondary characters such as their resistance to the main rubber diseases. Identification of resistance levels of rubber clones IRR 300 series had been done in the laboratories and greenhouse used the Completely Randomized Design with two factors, namely the type of rubber clone factor (26 clones) and $\mathrm{C}$. cassiicola isolate factor (3 isolates). In addition, it was also carried out direct field observation on immature rubber plant. The results showed that all of the $\mathrm{C}$. cassiicola isolates gave a significant effect to the resistance of 26 rubber clones IRR 300 series both in the laboratory and greenhouse. Observations on all of the experiment conditions showed that 13 rubber clones i.e IRR 301, IRR 302, IRR 303, IRR 304, IRR 305, IRR 307, IRR 308, IRR 309, IRR 312, IRR 315, IRR 316, IRR 318, and IRR 323 had a high level of resistance on Corynespora leaf fall disease.
\end{abstract}

Keywords: Corynespora casiicola; IRR 300 series rubber clones; leaf fall disease; rubber plant; toxin

\footnotetext{
Abstrak

Penyakit gugur daun Corynespora yang disebabkan oleh cendawan Corynespora cassiicola (C. cassiicola) merupakan salah satu penyakit daun penting yang dapat menyebabkan
}

penurunan produksi lateks pada perkebunan karet. Salah satu tahapan penting untuk melepaskan klon karet baru adalah mengidentifikasi karakter sekunder seperti resistensi terhadap penyakit. Pengujian resistensi klon karet IRR seri 300 dilakukan di laboratorium dan rumah kaca dengan menggunakan Rancangan Acak Lengkap dua faktor yaitu faktor jenis (genotipe) klon (26 jenis klon) dan isolat $C$. cassiicola (3 isolat). Selain itu, pengamatan serangan penyakit secara langsung juga dilakukan pada tanaman belum menghasilkan di lapangan. Hasil pengujian menunjukkan semua isolat $C$. cassiicola berpengaruh nyata terhadap resistensi 26 klon IRR seri 300 baik di laboratorium maupun di rumah kaca. Hasil pengamatan pada tiga kegiatan menunjukkan bahwa 13 klon karet yaitu IRR 301, IRR 302, IRR 303, IRR 304, IRR 305, IRR 307, IRR 308, IRR 309, IRR 312, IRR 315, IRR 316, IRR 318, dan IRR 323 memiliki tingkat resistensi tinggi terhadap penyakit gugur daun Corynespora.

Kata kunci: Corynespora cassiicola; klon IRR seri 300; penyakit gugur daun; tanaman karet; toksin

\section{PENDAHULUAN}

Penyakit gugur daun Corynespora (PGDC) merupakan salah satu penyakit penting pada perkebunan karet yang dapat menyebabkan kerugian ekonomi. PGDC pertama kali ditemukan pada tahun $1958 \mathrm{di}$ India, kemudian dilaporkan di Malaysia pada tahun 1960 dan Nigeria pada tahun 1966 (Jayasinghe \& Fernando, 2011). PGDC disebabkan oleh cendawan Corynespora cassiicola (Berk \& Curt) Wei (C. cassiicola) 
yang mulai menimbulkan kerusakan sejak tahun 1980-an di perkebunan karet Indonesia (Situmorang et al., 2004). Penyakit ini dapat menyerang tanaman karet pada segala tingkatan umur, baik pada pembibitan, kebun entres, maupun kebun produksi dengan pengguguran daun secara terus-menerus sepanjang tahun sehingga tanaman tidak dapat berproduksi dan lambat laun akan mati (Jayasinghe, 2000; Suryaningtyas, 2012).

Penyakit gugur daun Corynespora telah tersebar di seluruh perkebunan karet di Indonesia. Menurut Pawirosoemardjo (2004), perkembangan penyakit gugur daun Corynespora dipengaruhi oleh cuaca, topografi, umur, kondisi tanaman, dan jenis klon. Kerusakan yang ditimbulkan berbeda antar klon karet tergantung pada kondisi agroklimat. Kondisi agroklimat di dataran rendah pada umumnya sangat sesuai bagi perkembangan penyakit tersebut (Tan \& Tan, 1996). Kondisi lembab (>89\%) dan suhu $>27^{\circ} \mathrm{C}$ atau hujan panas bersamaan dengan tanaman membentuk daun muda merupakan kondisi efektif pemicu timbulnya epidemi penyakit. Apabila epidemi penyakit pada klon tertentu di suatu daerah terjadi maka epidemi tersebut akan berlanjut pada tahun berikutnya (Situmorang et al., 2004). Manju, Benagi, Shankarappa, Vinod, dan Jacob (2015) menambahkan bahwa serangan penyakit gugur daun pada tanaman karet di beberapa lokasi tidak terjadi secara acak, tetapi merata di alam dan tergantung pada lingkungannya.

Cendawan C. cassiicola menghasilkan toksin berupa senyawa glikoprotein yang disebut "cassiicolin". Toksin ini memiliki inang selektif karena mereproduksi pola gejala penyakit hanya dalam klon karet atau dalam tanaman inang yang rentan terhadap C. cassiicola. Gen cassiicolin mengkode protein prekursor yang mengandung gugus peptida pada asam amino yang diperkirakan menargetkan protein untuk disekresikan (Déon et al., 2012). Toksin tidak menunjukkan toksisitas pada klon karet yang tahan atau tanaman bukan inang (Breton \& D'Auzac, 1999).

Cara kerja toksin pada tanaman karet masih belum diketahui, tetapi toksin pada umumnya mengakibatkan peningkatan permeabilitas membran sel dan kematian sel karena pengaruhnya dapat mempercepat kelayuan daun. Toksin juga mempunyai efek elisitor skopoletin yang berperan dalam resistensi tanaman (Agrios, 2005). Breton, Sanier, dan D'Auzac (2000) menyatakan bahwa terdapat korelasi antara tingkat patogenitas dengan jumlah toksin yang dihasilkan. Menurut Jayasinghe dan Fernando (2011), toksin tersebut memainkan peran utama dalam perkembangan penyakit gugur daun pada tanaman karet.

Cendawan C. cassiicola menyerang daun karet yang masih muda atau berwarna kecokelatan. Gejala awal berupa bercak hitam terutama pada bagian urat atau tulang daun yang baru nampak setelah daun berwarna hijau muda atau tua. Selanjutnya, bercak berkembang mengikuti tulang atau urat daun, dan meluas ke urat-urat daun kecil di sekitarnya, sehingga bercak akan tampak menyirip seperti tulang-tulang ikan. Pada serangan lanjut bercak semakin meluas, berbentuk bundar atau tidak teratur. Bagian tepi bercak berwarna cokelat dan terdapat sirip-sirip berwarna cokelat atau hitam, sedangkan bagian pusatnya kering atau mati, warnanya cokelat kadangkadang berlubang. Gejala ini disebabkan adanya produksi toksin di lokasi infeksi. Selanjutnya, daerah sekitar lesi menjadi klorosis karena rusaknya kloroplas (Jayasinghe \& Fernando, 2011). Daun yang sakit tersebut lambat laun menjadi kuning atau cokelat kemudian gugur. Selain menyerang daun, patogen juga menyerang tangkai daun, pucuk, ranting, atau cabang tanaman (Suryaningtyas, 2012).

Penyakit gugur daun Corynespora ini sulit diatasi karena penyakit ini mengakibatkan kerusakan sepanjang tahun. Pengendalian penyakit yang dianggap lebih efisien pada saat ini adalah dengan penggunaan klon resisten, tetapi penggunaan klon resisten memiliki kelemahan karena resistensinya dapat dipatahkan oleh munculnya ras baru yang lebih virulen. Pemantauan perkembangan penyakit pada setiap klon perlu dilakukan secara sistematis (Situmorang et al., 2004).

Salah satu teknologi terpenting dalam meningkatkan produktivitas perkebunan karet adalah penggunaan klon unggul sebagai bahan tanam. Hal ini menjadi pendorong bagi pemulia karet untuk 
menghasilkan klon-klon yang lebih produktif di masa yang akan datang. Kegiatan pemuliaan tanaman karet yang telah dilakukan menghasilkan beberapa klon unggulan karet, antara lain GT 1 dan Tjir 1 (Klon Primer), AVROS 2037 (Klon Sekunder), serta klon IRR Seri 0, 100, 200, dan 300 sebagai Klon Tersier. Pengujian keragaman resistensi klon karet perlu dilakukan untuk mengidentifikasi tingkat resistensi klon terhadap penyakit gugur daun Corynespora sehingga dapat dijadikan acuan dalam melakukan penanaman tanaman karet.

\section{BAHAN DAN METODE}

Penelitian dilaksanakan di Laboratorium Proteksi Tanaman, Rumah Kaca, dan Kebun Percobaan Balai Penelitian Sembawa mulai bulan Desember 2015 sampai dengan bulan Oktober 2016. Penelitian terdiri dari tiga kegiatan yaitu (a) pengujian resistensi daun karet klon IRR seri 300 terhadap C. cassiicola di laboratorium, (b) pengujian resistensi klon IRR seri 300 terhadap C. cassiicola pada bibit di rumah kaca, dan (c) pengamatan resistensi klon IRR seri 300 di lapangan (kebun percobaan). Adapun rincian metode penelitian sebagai berikut:

1. Pengujian Resistensi Klon IRR Seri 300 terhadap C. casiicola di Laboratorium

\section{a. Pembuatan Toksin C. cassiicola}

Pengujian resistensi klon-klon karet IRR seri 300 dilakukan menggunakan filtrat toksin dari tiga isolat C. cassiicola yaitu CCRRIM 600, CC-GT 1, dan CC-PR 303. Ketiga isolat tersebut diisolasi dari klon karet RRIM 600, GT 1, dan PR 303. Toksin diproduksi dalam media cair Czapeck yang dimodifikasi (Situmorang, 2002), yaitu sebanyak $20 \mathrm{~mL}$ larutan mineral 20\%, 12 g sukrosa, dan 6 g agar dalam $1 \mathrm{~L}$ air destilata pada $\mathrm{pH} 4$. Media Czapeck tersebut diambil sebanyak $100 \mathrm{~mL}$ dan dimasukkan ke dalam gelas erlenmeyer $250 \mathrm{~mL}$ kemudian dimasukkan ke dalam autoclave pada suhu $110^{\circ} \mathrm{C}$ selama 20 menit. Setelah dingin, sebanyak tiga potong $(\varnothing 5$ $\mathrm{mm}$ ) biakan isolat $C$. cassiicola yang berasal dari tiga jenis klon dimasukkan ke permukaan media dalam keadaan terapung.
Gelas erlenmeyer berisi biakan isolat tersebut dimasukkan ke dalam stoples yang dialiri udara lembab semi-steril. Aliran udara lembab semi-steril diperoleh dengan memompakan udara bebas dengan alat pompa udara melalui saringan udara dan pipa ke dalam stoples wadah biakan. Tutup erlenmeyer dibuka sedikit untuk menjaga sirkulasi udara di atas permukaan media. Biakan diinkubasi pada suhu $25^{\circ} \mathrm{C}$ selama 15 hari, kemudian media biakan disaring dengan kertas saring Whatman 40. Penyaringan dilanjutkan dengan membran berpori 0,45 $\mu \mathrm{m}$. Toksin dimasukkan ke dalam botol dan disimpan dalam refrigerator pada suhu $\pm 5^{\circ} \mathrm{C}$.

Sebelum dilakukan pengujian toksisitas dengan perendaman helai daun, konsentrasi toksin diukur terlebih dahulu. Pengukuran dilakukan dengan cara mengendapkan $10 \mathrm{~mL}$ toksin dalam $100 \mathrm{~mL}$ etanol absolut dan dikeringkan pada suhu $40^{\circ} \mathrm{C}$ selama satu malam. Konsentrasi dihitung dari berat kering toksin setelah perendaman selama satu malam dan dibagi dengan volume larutan.

\section{b. Perendaman Helai Daun}

Pengujian resistensi klon terhadap penyakit gugur daun Corynespora menggunakan Rancangan Acak Lengkap dengan dua faktor, masing-masing perlakuan dilakukan ulangan sebanyak tiga kali, dari setiap ulangan diambil daun contoh sebanyak tiga tangkai daun (sembilan helai daun). Dua faktor perlakuan yang digunakan dalam percobaan yaitu:

1. Faktor perlakuan klon (26 jenis klon, yaitu: IRR 300, IRR 301, IRR 302, IRR 303, IRR 304, IRR 305, IRR 306, IRR 307, IRR 308, IRR 309, IRR 310, IRR 311, IRR 312, IRR 313, IRR 314, IRR 315, IRR 316, IRR 317, IRR 318, IRR 319, IRR 321, IRR 323, serta sebagai pembanding menggunakan klon GT 1, RRIM 600, RRIC 100, dan TJIR 1).

2. Faktor isolat (CC-RRIM 600, CC-GT 1, dan CC-PR 303). Ketiga isolat tersebut merupakan isolat yang tergolong memiliki virulensi tinggi ( ${ }^{a}$ Oktavia, Sudarsono, Kuswanhadi, Dinarty, \& Widodo, 2016). 
Perendaman helai daun dilakukan dengan memasukkan sebanyak $125 \mathrm{~mL}$ larutan filtrat toksin ke dalam baki plastik ukuran $20 \mathrm{~cm}$ x $30 \mathrm{~cm}$ x $5 \mathrm{~cm}$. Kemudian baki ditutup dengan styrofoam yang telah dilubangi sebanyak 30 buah $(\varnothing 3 \mathrm{~cm})$. Melalui lubang tersebut dimasukkan sebanyak tiga helai daun jenuh air dengan bagian pangkalnya terendam $\pm 0,5 \mathrm{~cm}$ dalam toksin C. cassiicola. Daun jenuh air tersebut diperoleh dengan mencelupkan bagian pangkal daun dalam air destilata selama satu malam. Selanjutnya perlakuan tersebut diinkubasi pada suhu kamar selama dua hari.

\section{c. Pengamatan dan Analisis Data}

Pengamatan dilakukan dengan menghitung persentase kelayuan daun dan virulensi isolat patogen C. cassiicola terhadap keparahan penyakit pada daun setelah 48 jam perlakuan. Perbedaan kerentanan masing-masing daun digambarkan dengan menghitung kehilangan bobot daun 48 jam setelah perlakuan toksin C. cassiicola. Persentase kelayuan daun dihitung dengan rumus sebagai berikut (Situmorang, 2002):

$\mathrm{PKD}=\left[\frac{(\mathrm{BBO}-\mathrm{BBT})}{\mathrm{BBO} \text { perlakuan }} \times 100 \%\right]-\left[\frac{(\mathrm{BBO}-\mathrm{BBT})}{\mathrm{BBT} \text { kontrol }} \times 100 \%\right] \ldots$

Keterangan (Remaks):

$\mathrm{PKD}=$ persentase kelayuan daun

$\mathrm{BbO}=$ bobot basah sebelum perlakuan toksin

$\mathrm{BBT}=$ bobot basah setelah perlakuan toksin

Berdasarkan persentase kelayuan daun tersebut, tingkat resistensi masingmasing klon selanjutnya dikelompokkan menjadi empat kelompok, yaitu sangat resisten, resisten, rentan, dan sangat rentan berdasarkan nilai standar deviasi (SD) dimana kurang dari nilai rata-rata -1 SD digolongkan sebagai tanaman sangat resisten, - 1 SD sampai nilai rata-rata sebagai tanaman resisten, rata-rata sampai $+1 \mathrm{SD}$ sebagai tanaman rentan dan lebih dari nilai rata-rata +1 SD digolongkan sebagai tanaman sangat rentan.

Interaksi antara klon dengan isolat dianalisis dengan metode ANOVA dua faktor (klon dan isolat) menggunakan program SAS (Statistical Analysis System) dan diuji lanjut menggunakan Duncan Multiple Range Test (DMRT).
2. Pengujian Resistensi Klon IRR Seri 300 terhadap C. cassiicola Pada Bibit di Rumah Kaca

Pengujian dilakukan pada bibit karet dalam polibeg dengan menggunakan Rancangan Acak Lengkap dua faktor dengan tiga ulangan. Faktor perlakuan yang digunakan adalah jenis klon karet dan jenis isolat C. cassiicola. Setiap ulangan terdiri dari tiga unit tangkai daun.

\section{a. Produksi Inokulum Patogen}

Produksi inokulum patogen dilakukan dengan metode Situmorang (2002). Inokulum yang digunakan adalah konidia patogen. Konidia C. cassiicola diproduksi dengan membuat biakan murni ketiga isolat pada media PDA dalam cawan petri. Sebanyak 8-10 potong (Ø $5 \mathrm{~mm}$ ) biakan isolat tersebut diletakkan dengan posisi terbalik pada permukaan bawah daun steril dalam cawan petri sehingga miselia kontak langsung ke permukaan daun. Daun yang digunakan adalah daun hijau muda berumur 3-4 minggu dari klon karet asal masing-masing isolat yang diuji untuk mempertahankan virulensi isolat, sedangkan sterilisasi daun menggunakan autoklav pada suhu $110^{\circ} \mathrm{C}$. Setelah 3-4 hari inkubasi, posisi daun dibalik. Konidia akan terbentuk pada permukaan atas daun 4-5 hari setelah posisi daun dibalik. Setelah konidia terbentuk, daun dikeringanginkan terlebih dahulu pada suhu kamar selama satu hari agar pelepasan konidia dari tangkainya lebih mudah. Konidia yang terbentuk tersebut dilepas dari daun dengan menggunakan kuas. Selanjutnya konidia dimasukkan ke dalam Erlenmeyer yang telah berisi air steril dan disaring menggunakan kain kassa untuk memisahkan konidia yang menggumpal. Konsentrasi konidia dihitung menggunakan haemocytometer di bawah mikroskop.

b. Inokulasi Konidia Patogen pada Bibit Karet dalam Polibeg

Inokulasi dilakukan dengan menyemprotkan sebanyak $1 \mathrm{~mL}$ inokulum konsentrasi $4 \times 10^{4}$ konidia/mL dengan menggunakan sprayer pada permukaan bawah daun tanaman. Daun yang digunakan merupakan daun muda (berwarna cokelat). Daun tersebut kemudian disungkup menggunakan kantong plastik transparan untuk mempertahankan 
kelembaban selama inkubasi. Empat hari setelah inkubasi, sungkup plastik dilepas dan dibiarkan selama delapan hari untuk diamati.

\section{c. Pengamatan dan Analisis Data}

Pengamatan virulensi isolat patogen ditentukan berdasarkan keparahan penyakit pada daun. Pengukuran intensitas serangan penyakit dilakukan 12 hari setelah inokulasi konidia. Pengamatan dilakukan dengan menggunakan skala serangan yang dikelompokkan pada Tabel 1 .

Hasil pengukuran skala serangan dimasukkan dalam rumus yang dikembangkan oleh Towsendt \& Hueberger sebagai berikut (Sinaga, 2006):

Tabel 1. Klasifikasi skala serangan C. cassiicola pada daun

Table 1. Classification of C. cassiicola attacks scale on leaves

\begin{tabular}{cl}
\hline $\begin{array}{c}\text { Skala serangan } \\
\text { Attacks scale }\end{array}$ & \multicolumn{1}{c}{$\begin{array}{c}\text { Klasifikasi } \\
\text { Classification }\end{array}$} \\
\hline 0 & Tidak ada serangan \\
1 & Terdapat gejala bercak cokelat kehitaman \\
2 & $1-50 \%$ luasan daun berwarna kuning kecokelatan \\
3 & $51-100 \%$ luasan daun berwarna kuning kecokelatan atau gugur \\
\hline
\end{tabular}

IP $=\frac{\sum_{\mathrm{i}=1}^{\mathrm{n}} \mathrm{n} \cdot \mathrm{v}}{\mathrm{Z} \cdot \mathrm{N}} \times 100 \%$

Keterangan (Remaks):

IP : intensitas penyakit;

$\mathrm{n}$ : jumlah tanaman berskala v;

$\mathrm{v}$ : skala ke-i; dan

Z : nilai skor tertinggi.

$\mathrm{N}$ : jumlah tanaman yang diamati

Berdasarkan hasil persentase keparahan penyakit tersebut, tingkat virulensi isolat patogen dikelompokkan sebagai berikut (modifikasi Situmorang, 2002):
Data intensitas serangan penyakit dianalisis menggunakan One Way Anova dan diuji lanjut menggunakan Duncan Multiple Range Test dalam program Statistical Analysis System (SAS).

3. Pengamatan Resistensi Klon IRR Seri 300 pada Tanaman Belum Menghasilkan di Lapangan

Pengamatan resistensi 26 klon IRR seri 300 terhadap penyakit gugur daun Corynespora dilakukan pada tanaman belum menghasilkan (TBM) umur tiga tahun yang dilakukan secara visual dengan melihat gejala serangan penyakit pada tanaman. Pengamatan dilakukan pada daun muda berwarna cokelat dan hijau.

Tabel 2. Klasifikasi tingkat virulensi $C$. cassiicola Table 2. Classification of C. cassiicola virulence level

\begin{tabular}{|c|c|}
\hline $\begin{array}{c}\text { Skala serangan } \\
\text { Attacks scale } \\
(\%)\end{array}$ & $\begin{array}{c}\text { Klasifikasi } \\
\text { Classification }\end{array}$ \\
\hline $0-5 \%$ & Tidak virulen (avirulen) atau tanaman sangat resisten \\
\hline $6-33 \%$ & Virulensi agak rendah (kurang virulen) atau tanaman resisten \\
\hline $34-67 \%$ & Virulensi moderat virulen atau tanaman rentan \\
\hline $68-100 \%$ & Virulensi (sangat virulen) atau tanaman sangat rentan \\
\hline
\end{tabular}




\section{HASIL DAN PEMBAHASAN}

\section{Pengujian Resistensi Klon IRR Seri 300 terhadap C. casiicola di Laboratorium}

Berdasarkan persentase kelayuan daun klon IRR Seri 300 terhadap tiga filtrat toksin C. cassiicola yang digunakan terlihat bahwa setiap klon memiliki tingkat resistensi yang berbeda terhadap setiap isolat yang digunakan (Gambar 1). Perbedaan tersebut dapat terjadi karena adanya interaksi antara gen-gen pertahanan pada klon karet dengan gen-gen virulensi pada isolat. Hal tersebut sejalan dengan penelitian sebelumnya yang menyatakan bahwa setiap klon karet memiliki tingkat resistensi yang berbeda terhadap isolat $C$. cassiicola (Situmorang et al., 2000; Hadi et al., 2004; ${ }^{\mathrm{b} O k t a v i a ~ e t ~ a l ., ~ 2016) . ~}$

Hasil perhitungan persentase ratarata kelayuan daun semua klon pada setiap isolat berkisar antara 16,59\% - 22,58\%. Persentase kelayuan daun tertinggi ditemukan pada isolat CC-RRIM 600 (Gambar 2). Hal ini dapat disebabkan karena CC-RRIM 600 merupakan isolat yang memiliki tingkat virulensi tinggi. Selain itu, Situmorang et al (2007) juga melaporkan bahwa klon karet RRIM 600 merupakan sumber infeksi penting karena klon tersebut ditanam dalam skala luas pada perkebunan karet di Indonesia sehingga diperkirakan patogen (spora udara) dari klon tersebut terdapat dalam jumah besar di alam.

Berdasarkan rata-rata persentase kelayuan daun dari 26 klon karet IRR Seri 300 dan klon pembanding terhadap tiga isolat C. cassiicola diperoleh nilai rata-rata sebesar 19,01 dan standar deviasi (SD) sebesar 6,78. Nilai tersebut selanjutnya digunakan sebagai dasar pengelompokkan tingkat resistensi klon karet terhadap PGDC. Genotipe dengan persentase kelayuan daun di bawah atau sama dengan rata-rata dikurang standar deviasi yaitu sebesar $12,22 \%$ digolongkan sebagai kelompok klon karet sangat resisten terhadap PGDC; $12,23 \%-19,00 \%$ digolongkan sebagai

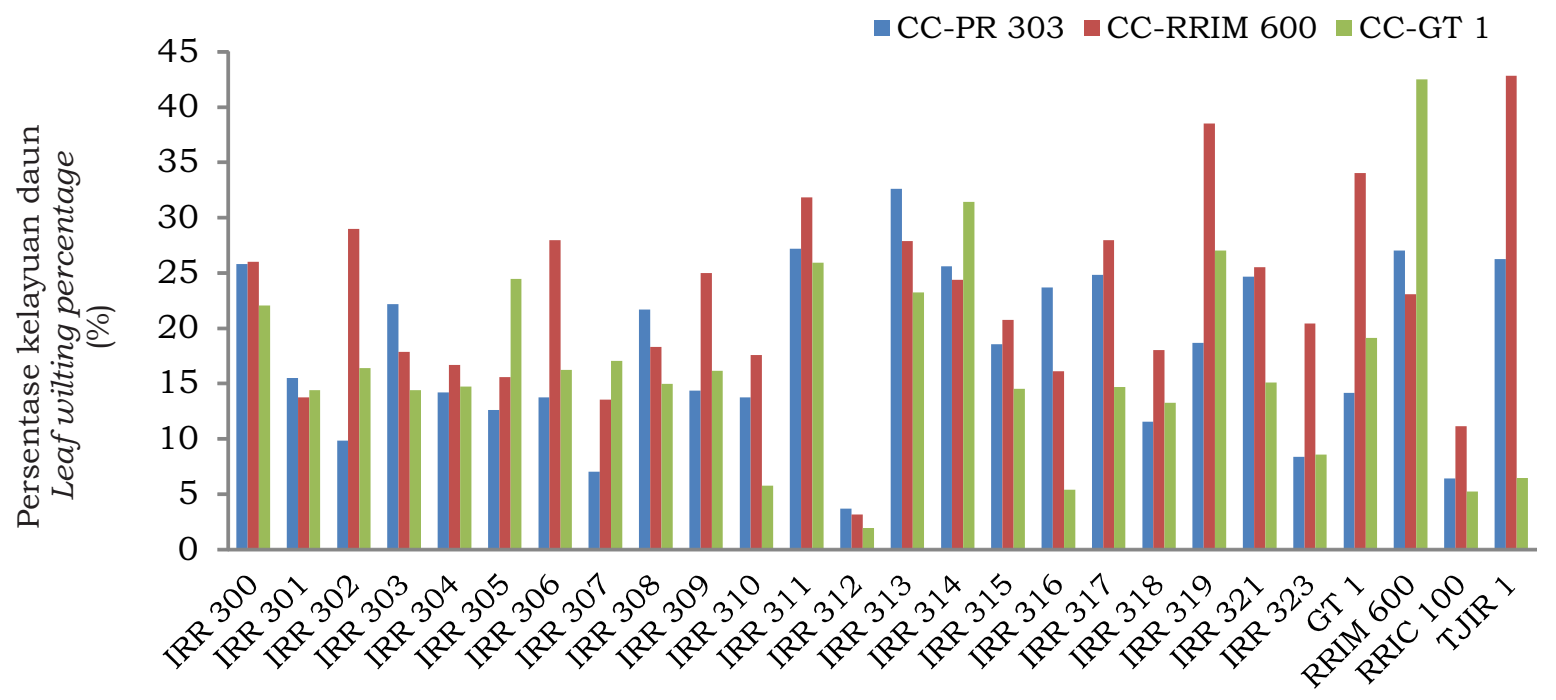

Klon karet

Rubber clone

Gambar 1. Persentase kelayuan daun berbagai klon karet IRR seri 300 terhadap tiga isolat C. cassiicola CC-PR 303, CC-RRIM 600, dan CC-GT 1.

Figure 1. Percentage of leaf wilting of IRR series 300 rubber clones to three of C. cassiicola isolates CC-PR 303, CC-RRIM 600, dan CC-GT 1. 


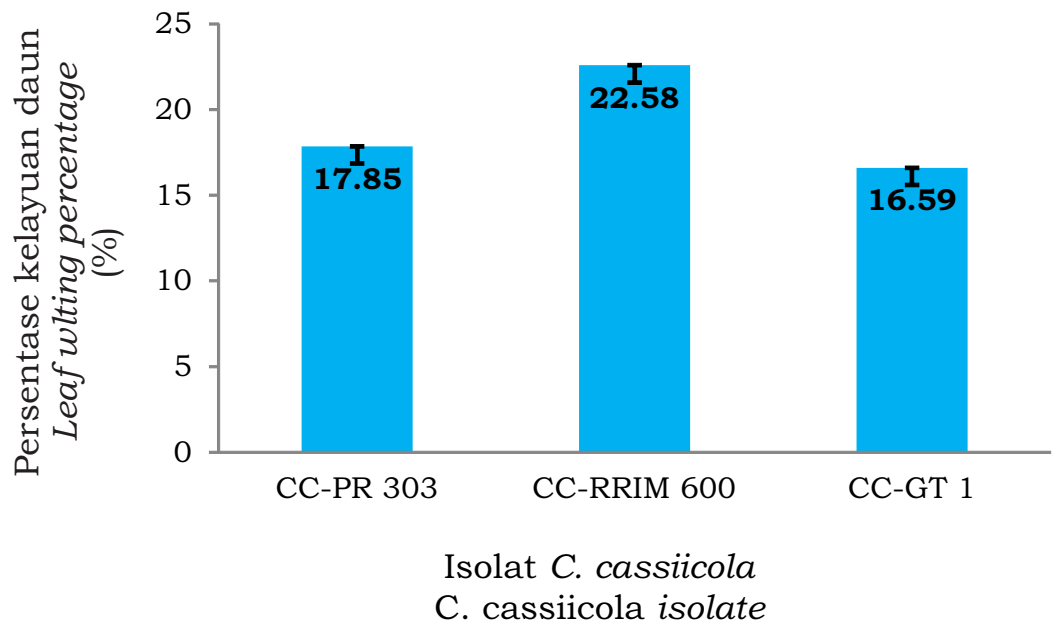

Gambar 2. Persentase kelayuan daun berbagai klon karet IRR Seri 300 terhadap tiga isolat C. cassiicola CC-PR 303, CC-RRIM 600, dan CC-GT 1.

Figure 2. Percentage of leaf wilting of IRR Series 300 rubber clones to three of C. cassiicola isolates CC-PR 303, CC-RRIM 600, dan CC-GT 1.

kelompok klon karet resisten; 19,01\% $25,78 \%$ digolongkan sebagai kelompok klon karet rentan; dan lebih dari 25,79\% sebagai kelompok klon karet sangat rentan. Berdasarkan nilai tersebut terdapat dua klon karet yang diuji merupakan klon yang tergolong sangat resisten, 13 klon karet tergolong resisten, enam klon karet tergolong rentan, dan lima klon karet tergolong sangat rentan terhadap PGDC (Tabel 3).

Pengujian terhadap 22 klon karet IRR Seri 300 dan klon pembanding menunjukkan bahwa klon karet dengan tingkat resistensi paling tinggi adalah klon IRR 312 dengan persentase kelayuan daun sebesar 2,94\% dan tingkat resistensi paling rendah adalah RRIM 600 dengan persentase kelayuan daun sebesar 30,88\%. Apabila dibandingkan dengan klon pembanding terlihat bahwa tingkat resistensi klon IRR 312 jauh lebih baik sehingga berpotensi dijadikan sebagai sumber gen ketahanan terhadap penyakit gugur daun Corynespora. Berdasarkan hasil tingkat resistensi klon IRR seri 300 yang berbeda terhadap setiap isolat terlihat bahwa isolat patogen asal klon karet dapat memiliki virulensi yang tinggi pada klon karet lainnya (Situmorang, 2002; Kusdiana \& Oktavia, 2014; Kusdiana \& Syafaah, 2015).

\section{Pengujian Resistensi Klon IRR Seri 300 terhadap C. cassiicola pada Bibit di Rumah Kaca}

Hasil penelitian di tingkat rumah kaca menunjukkan adanya tingkat virulensi yang berbeda antar setiap jenis isolat (Gambar 3). Hasil perhitungan rata-rata persentase kelayuan daun semua klon pada setiap isolat berkisar antara $13,96 \%$ $19,61 \%$ dengan persentase tertinggi ditemukan pada isolat CC-PR 303 (Gambar 4). Pengaruh perlakuan spora terhadap intensitas serangan penyakit menunjukkan bahwa spora C. cassiicola CC-PR 303 memiliki pengaruh paling besar dibanding jenis spora lainnya yaitu sebesar 19,61\%. Namun, nilai pengaruh spora C. cassiicola CC-RRIM 600 tidak berbeda sedangkan spora C. cassiicola CC-GT 1 lebih kecil dari spora C. cassiicola CC-PR 303. Hal ini disebabkan karena kedua isolat CC-PR 303 dan CC-RRIM 600 merupakan isolat yang tergolong sangat virulen, sedangkan CC-GT 1 tergolong virulensi tinggi ('Oktavia et al., 2016).

Tingginya pengaruh dari ketiga spora mungkin dikarenakan klon karet tersebut telah ditanam dalam skala luas pada perkebunan karet Indonesia, sehingga spora udara dari patogen tersebut terdapat 
Tabel 3. Persentase kelayuan daun klon karet IRR Seri 300 akibat penyakit gugur daun Corynespora pada skala laboratorium

Table 3. Percentage of leaf wilting of IRR Series 300 rubber clones caused by Corynespora leaf fall disease on laboratory scale

\begin{tabular}{|c|c|c|c|}
\hline No & $\begin{array}{l}\text { Klon } \\
\text { Clones }\end{array}$ & $\begin{array}{c}\text { Persentase kelayuan daun } \\
\text { Percentage of leaf wilting } \\
(\%)\end{array}$ & $\begin{array}{c}\text { Tingkat virulensi } \\
\text { Virulence level }\end{array}$ \\
\hline 1 & IRR 300 & 24,62 abcdef & Rentan \\
\hline 2 & IRR 301 & $14,56 \mathrm{fgh}$ & Resisten \\
\hline 3 & IRR 302 & 18,42 bcdefg & Resisten \\
\hline 4 & IRR 303 & 18,15 bcdefg & Resisten \\
\hline 5 & IRR 304 & 15,20 efgh & Resisten \\
\hline 6 & IRR 305 & 17,54 defg & Resisten \\
\hline 7 & IRR 306 & 19,33 bcdefg & Rentan \\
\hline 8 & IRR 307 & $12,54 \mathrm{gh}$ & Resisten \\
\hline 9 & IRR 308 & 18,32 bcdefg & Resisten \\
\hline 10 & IRR 309 & $18,51 \mathrm{bcdefg}$ & Resisten \\
\hline 11 & IRR 310 & $12,38 \mathrm{~g}$ & Resisten \\
\hline 12 & IRR 311 & $28,33 \mathrm{ab}$ & Sangat rentan \\
\hline 13 & IRR 312 & $2,94 \mathrm{i}$ & Sangat resisten \\
\hline 14 & IRR 313 & $27,92 \mathrm{abc}$ & Sangat rentan \\
\hline 15 & IRR 314 & 27,14 abcd & Sangat rentan \\
\hline 16 & IRR 315 & 17,96 cdefg & Resisten \\
\hline 17 & IRR 316 & 15,08 efgh & Resisten \\
\hline 18 & IRR 317 & 22,50 abcdefg & Rentan \\
\hline 19 & IRR 318 & $14,29 \mathrm{gh}$ & Resisten \\
\hline 20 & IRR 319 & $28,07 \mathrm{abc}$ & Sangat rentan \\
\hline 21 & IRR 321 & 21,76 abcdefg & Rentan \\
\hline 22 & IRR 323 & $12,47 \mathrm{gh}$ & Resisten \\
\hline 23 & GT 1 & 22,44 abcdefg & Rentan \\
\hline 24 & RRIM 600 & $30,88 \mathrm{~g}$ & Sangat rentan \\
\hline 25 & RRIC 100 & $7,60 \mathrm{~h}$ & Sangat resisten \\
\hline 26 & TJIR 1 & 25,19 abcde & Rentan \\
\hline
\end{tabular}

*Angka-angka yang diikuti huruf yang sama pada kolom yang sama tidak berbeda nyata berdasarkan Uji Jarak Berganda Duncan 5\%

*Number followed by the same letter in the same coloumn were not significantly different based on DMRT at 0,05 


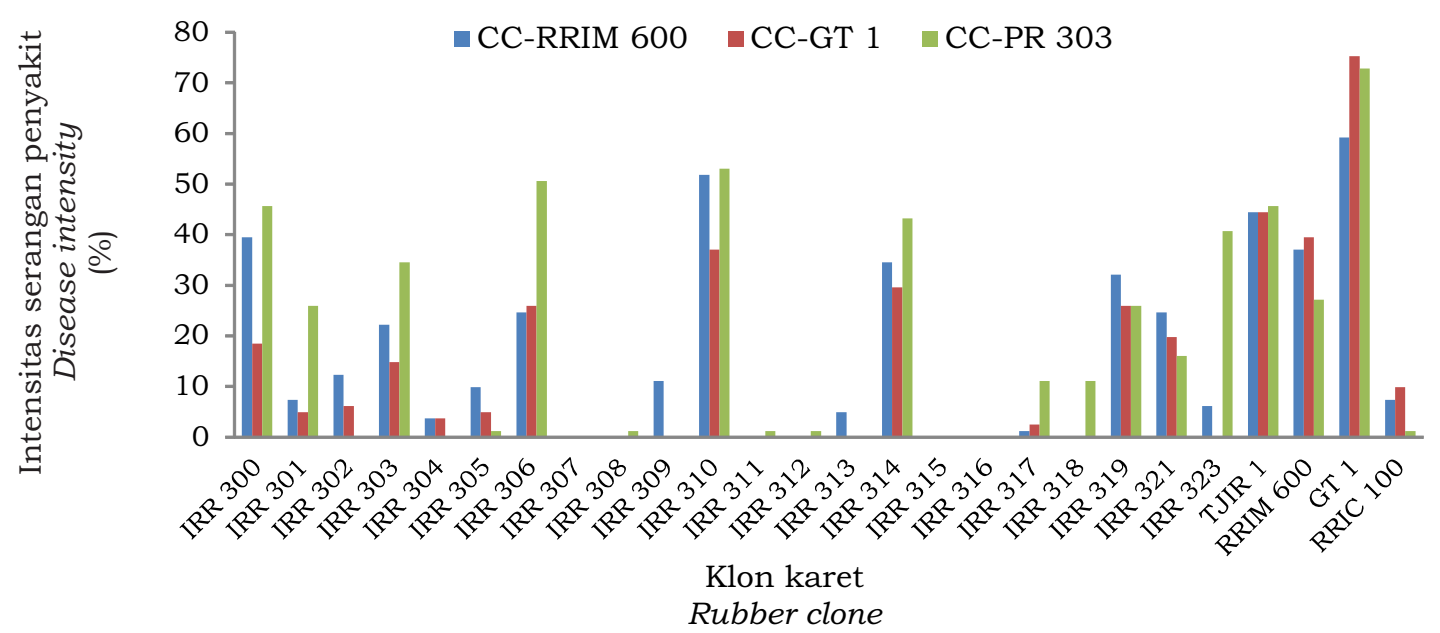

Gambar 3. Intensitas serangan penyakit Corynespora berbagai klon karet IRR seri 300 terhadap tiga isolat C. cassiicola CC-PR 303, CC-RRIM 600, dan CC-GT 1.

Figure 3. Corynespora leaffall disease intensity of IRR series 300 rubber clones to three of C. cassiicola isolates CC-PR 303, CC-RRIM 600, and CC-GT 1.

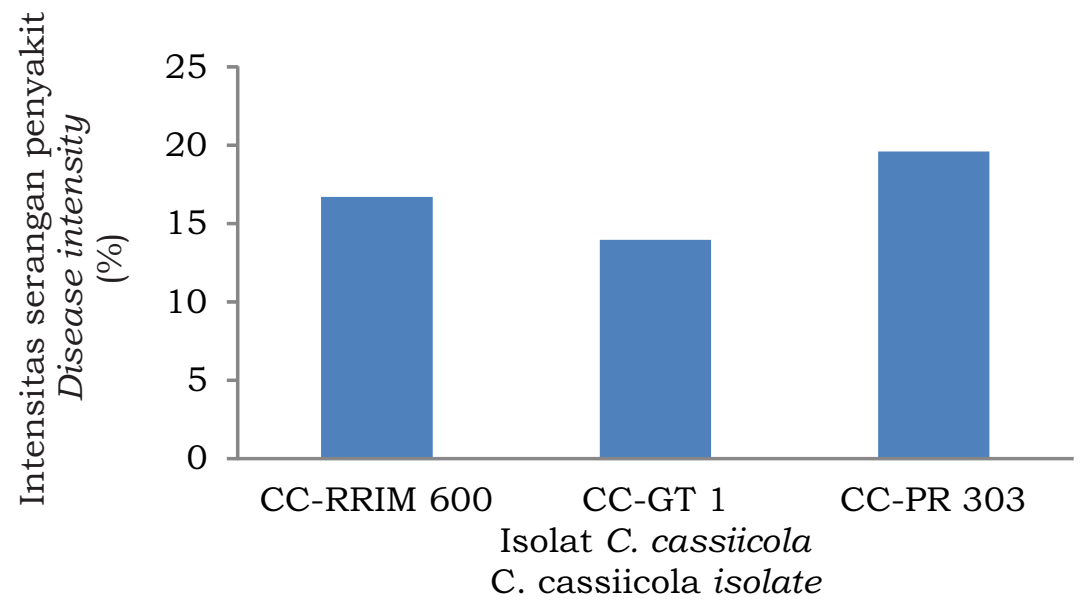

Gambar 4. Intensitas serangan penyakit Corynespora berbagai klon karet IRR Seri 300 terhadap tiga isolat C. cassiicola CC-PR 303, CC-RRIM 600, dan CC-GT 1.

Figure 4. Corynespora leaffall disease intensity of IRR series 300 rubber clones to three ofC. cassiicola isolates CC-PR 303, CC-RRIM 600, and CC-GT 1.

dalam jumlah besar di alam. Semakin lama suatu klon ditanam, maka semakin lama kemungkinan proses evolusi patogen untuk menyesuaikan diri sudah dilakukan (konsep kesesuaian lock and key antara gen patogen dengan gen tanaman atau gene for gene). Patogen akan selalu melakukan mutasi mengubah gen virulensinya agar sesuai dengan gen resistensi tanaman, sehingga resistensi tanaman dapat terpatahkan. Apabila penanaman dalam skala luas dan waktu yang lama, maka kesempatan gen virulensi patogen untuk berevolusi semakin besar, karena sifat ketahanan satu klon yang sama. Selain itu, ras baru patogen terbentuk akibat evolusi atau mutasi gen virulensi isolat. Isolat berusaha melakukan mutasi untuk mematahkan resistensi suatu klon.

Intensitas serangan penyakit pada bibit karet klon IRR Seri 300 menunjukkan respon yang berbeda terhadap serangan penyakit gugur daun Corynespora pada bibit karet (Tabel 4). Dari 22 klon karet IRR seri 300 , terdapat 12 klon yang memiliki tingkat resistensi sangat resisten yaitu klon IRR 304, IRR 305, IRR 307, IRR 308, IRR 309, IRR 311 , IRR 312, IRR 313, IRR 315, IRR 316, IRR 317, 
Tabel 4. Intensitas serangan penyakit gugur daun Corynespora pada klon karet IRR Seri 300 skala rumah kaca

Table 4. Corynespora leaffall disease intensity of IRR Series 300 rubber clones on greenhouse scale

\begin{tabular}{|c|c|c|c|}
\hline No & $\begin{array}{l}\text { Klon } \\
\text { Clones }\end{array}$ & $\begin{array}{c}\text { Intensitas serangan penyakit } \\
\text { Disease intensity } \\
(\%)\end{array}$ & $\begin{array}{l}\text { Tingkat virulensi } \\
\text { Virulence level }\end{array}$ \\
\hline 1 & IRR 300 & $34,57 \mathrm{~cd}$ & rentan \\
\hline 2 & IRR 301 & $12,76 \mathrm{gh}$ & resisten \\
\hline 3 & IRR 302 & $6,17 \mathrm{gh}$ & resisten \\
\hline 4 & IRR 303 & $23,87 \mathrm{def}$ & resisten \\
\hline 5 & IRR 304 & $2,47 \mathrm{~h}$ & sangat resisten \\
\hline 6 & IRR 305 & $5,35 \mathrm{gh}$ & sangat resisten \\
\hline 7 & IRR 306 & $33,75 \mathrm{~cd}$ & resisten \\
\hline 8 & IRR 307 & $0,00 \mathrm{~h}$ & sangat resisten \\
\hline 9 & IRR 308 & $0,41 \mathrm{~h}$ & sangat resisten \\
\hline 10 & IRR 309 & $3,70 \mathrm{gh}$ & sangat resisten \\
\hline 11 & IRR 310 & $47,33 \mathrm{~b}$ & rentan \\
\hline 12 & IRR 311 & $0,41 \mathrm{~h}$ & sangat resisten \\
\hline 13 & IRR 312 & $0,41 \mathrm{~h}$ & sangat resisten \\
\hline 14 & IRR 313 & $1,65 \mathrm{~h}$ & sangat resisten \\
\hline 15 & IRR 314 & $35,81 \mathrm{~cd}$ & rentan \\
\hline 16 & IRR 315 & $0,00 \mathrm{~h}$ & sangat resisten \\
\hline 17 & IRR 316 & $0,00 \mathrm{~h}$ & sangat resisten \\
\hline 18 & IRR 317 & $4,94 \mathrm{gh}$ & sangat resisten \\
\hline 19 & IRR 318 & 3,70 gh & sangat resisten \\
\hline 20 & IRR 319 & $27,98 \mathrm{de}$ & resisten \\
\hline 21 & IRR 321 & 20,17 ef & resisten \\
\hline 22 & IRR 323 & $15,64 \mathrm{fg}$ & resisten \\
\hline 23 & GT 1 & $69,14 \mathrm{a}$ & rentan \\
\hline 24 & RRIM 600 & $34,57 \mathrm{~cd}$ & rentan \\
\hline 25 & RRIC 100 & $6,17 \mathrm{gh}$ & resisten \\
\hline 26 & TJIR 1 & $44,86 \mathrm{bc}$ & rentan \\
\hline
\end{tabular}

Angka-angka yang diikuti huruf yang sama pada kolom yang sama tidak berbeda nyata berdasarkan Uji Jarak Berganda Duncan 5\%

Number followed by the same letter in the same coloumn were not significantly different based on DMRT at 0,05

dan IRR 318. Klon-klon tersebut memiliki nilai yang tidak berbeda antar klon dengan nilai intensitas serangan penyakit berkisar antara 0 sampai dengan $5,35 \%$. Tingginya resistensi pada klon IRR seri 300 diduga karena patogen $C$. cassiicola belum terstimulasi membentuk isolat yang virulen dan tekanan seleksi terhadap patogen untuk membentuk ras baru belum terjadi karena luas pertanaman klon IRR Seri 300 relatif masih terbatas di lapangan. Selain itu, secara umum klon-klon tetua yang digunakan untuk menghasilkan klon IRR Seri 300 adalah klon-klon yang tergolong moderat resisten hingga sangat resisten terhadap PGDC. Secara genetik sifat resistensi tersebut akan diturunkan, meskipun tidak akan selalu terekspresi, karena sifat dominan resesif pada karakter resistensi. 
Selain klon IRR Seri 300 terdapat satu klon pembanding RRIC 100 yang memiliki tingkat ketahanan resisten dibanding klon pembanding lainnya. Klon RRIC 100 yang ditanam secara luas di lapangan tidak atau belum terserang PGDC kemungkinan secara genetik klon tersebut sangat resisten terhadap serangan PGDC dan resistensi tersebut belum terpatahkan oleh isolat C. cassiicola. Resistensi klon RRIC 100 terhadap PGDC belum tentu selamanya dapat bertahan, ada kemungkinan suatu saat resistensi klon dapat terpatahkan, karena secara alami isolat selalu berusaha berevolusi atau bermutasi untuk mematahkan resistensi suatu klon.
Pengamatan Resistensi Klon IRR Seri 300 pada Tanaman Belum Menghasilkan di Lapangan

Pengamatan resistensi klon IRR Seri 300 pada TBM di lapangan dilakukan secara visual pada 22 klon IRR seri 300 dan satu klon pembanding yaitu BPM 24 (Tabel 5).

Hasil pengamatan secara visual di lapangan menunjukkan bahwa klon IRR Seri 300 memiliki tingkat resistensi yang lebih baik terhadap serangan penyakit gugur daun Corynespora dibandingkan klon BPM 24 pada pengujian di Sembawa, Sumatera Selatan. Semua klon memiliki tingkat resistensi yang resisten, kecuali pada klon

Tabel 5. Tingkat resistensi TBM umur tiga tahun klon IRR seri 300 terhadap penyakit gugur daun Corynespora

Table 5. Resistance level of IRR 300 series immature rubber plants to Corynespora leaf fall disease

\begin{tabular}{rcc}
\hline \multicolumn{1}{r|}{ No } & Klon & $\begin{array}{c}\text { Tingkat virulensi } \\
\text { Virulence level }\end{array}$ \\
\hline 1 & IRR 300 & Resisten \\
2 & IRR 301 & Resisten \\
3 & IRR 302 & Resisten \\
4 & IRR 303 & Resisten \\
5 & IRR 304 & Resisten \\
6 & IRR 305 & Resisten \\
7 & IRR 306 & Resisten \\
8 & IRR 307 & Resisten \\
9 & IRR 308 & Resisten \\
10 & IRR 309 & Resisten \\
11 & IRR 310 & Resisten \\
12 & IRR 311 & Resisten \\
13 & IRR 312 & Resisten \\
14 & IRR 313 & Rentan \\
15 & IRR 314 & Rentan \\
16 & IRR 315 & Resisten \\
17 & IRR 316 & Resisten \\
18 & IRR 317 & Resisten \\
19 & IRR 318 & Resisten \\
20 & IRR 319 & Resisten \\
21 & IRR 321 & Resisten \\
22 & IRR 323 & Resisten \\
23 & BPM 24 & Rentan \\
\hline & &
\end{tabular}


IRR 313 dan IRR 314 yang memiliki tingkat resistensi rentan. Hasil pengamatan pada TBM karet klon IRR Seri 300 di plot promosi Kebun Percobaan Sungei Putih, Sumatera Utara juga menunjukkan hasil yang sama bahwa klon IRR Seri 300 memiliki resistensi tinggi (tahan) terhadap penyakit gugur daun Corynespora (Woelan, Sayurandi, \& Pasaribu, 2012). Tingginya tingkat resistensi klon IRR Seri 300 terhadap PGDC memberikan indikasi bahwa klon-klon tersebut cukup baik ditanam dalam skala luas.

Beberapa klon menunjukkan tingkat resistensi yang berbeda terhadap PGDC pada berbagai tingkat pengujian seperti klon IRR 300, IRR 306, IRR 310, IRR 311, IRR 313, IRR 317, IRR 319, dan IRR 321. Pengujian pada tingkat laboratorium menunjukkan bahwa klon-klon tersebut rentan terhadap PGDC, namun pengujian rumah kaca dan pengamatan di lapangan menunjukkan bahwa klon-klon tersebut resisten terhadap PGDC. Begitu juga sebaliknya, pengujian di tingkat laboratorium yang menunjukkan suatu klon tahan seperti yang ditemukan pada klon IRR 310. Pada pengujian resistensi tanaman perbedaan ini seringkali terjadi karena adanya berbagai faktor yang mempengaruhi tingkat keparahan suatu penyakit pada suatu lokasi yaitu genetik tanaman, genetik patogen, dan lingkungan. Hal ini menyebabkan pengujian di rumah kaca seringkali lebih sesuai dengan kondisi pengamatan penyakit di lapangan. Hal yang sama juga dilaporkan oleh Fernando, Jayasinghe, Wijesundera, Silva, dan Nishantha (2010) yang menyatakan bahwa klon RRIC 100 dan RRIC 121 menunjukkan perbedaan tingkat resistensi terhadap PGDC pada pengujian ditingkat laboratorium dengan rumah kaca dan di lapangan. Pengujian melalui inokulasi spora di laboratorium menunjukkan bahwa kedua klon tersebut rentan terhadap PGDC, sedangkan pengujian di rumah kaca dan pengamatan di lapangan menunjukkan bahwa kedua klon tersebut resisten terhadap PGDC.

Ketiga skala pengujian baik di laboratorium, rumah kaca, dan observasi di lapangan perlu dilakukan, karena ketiga skala pengujian tersebut memberi informasi yang penting serta saling melengkapi. Secara umum pengujian pada tingkat laboratorium lebih menekankan kepada pengujian terhadap faktor genetik tanaman dan faktor genetik patogen dengan meminimalkan pengaruh faktor lingkungan. Hasil pengujian di tingkat laboratorium dapat dijadikan sebagai informasi awal dalam identifikasi resistensi klon-klon baru. Selain itu informasi tingkat resistensi di laboratorium yang lebih menekankan ke genetik dari suatu tanaman dapat digunakan sebagai informasi dalam pemilihan klon-klon yang akan dijadikan tetua sebagai sumber gen ketahanan dalam program pemuliaan. Namun untuk pelepasan suatu klon yang akan ditanam pada berbagai kondisi lingkungan diperlukan informasi resistensi di lapangan. Apabila pengujian hanya dilakukan di tingkat rumah kaca atau lapangan, kemungkinan informasi resistensi hanya untuk lingkungan dengan kondisi yang hampir sama dengan lingkungan pengujian, kecuali apabila pengujian sudah dilakukan pada multi lokasi. Umumnya hasil pengujian skala rumah kaca selaras dengan hasil observasi di lapangan, dan kadang kala sedikit berbeda dengan hasil pengujian di laboratorium. Oleh karena itu, hasil terbaik pada tiga tahap pengujian yang dianjurkan menjadi klon tahan.

\section{KESIMPULAN}

Hasil pengujian menunjukkan bahwa klon IRR seri 300 memiliki tingkat resistensi tinggi terhadap serangan penyakit gugur daun Corynespora. Resistensi daun terhadap toksin C. cassicola di laboratorium, pengujian keparahan penyakit terhadap spora $C$. cassiicola pada bibit karet dalam polibeg, serta pengamatan pada TBM klon IRR seri 300 di lapangan menunjukkan klon IRR 301, IRR 302, IRR 303, IRR 304, IRR 305, IRR 307, IRR 308, IRR 309, IRR 312, IRR 315, IRR 316, IRR 318, dan IRR 323 memiliki tingkat resistensi lebih tinggi terhadap penyakit gugur daun Corynespora dibandingkan klon IRR seri 300 lainnya.

\section{DAFTAR PUSTAKA}

Agrios, G.N. (2005). Plant pathology. Amsterdam, Netherlands: Elsevier Academic Press. 
Breton, F., \& D'Auzac, J. (1999). Cassiicoline, a host-selective toxin produced by Corynespora cassiicola, a casual agent of Hevea leaf fall disease. Proceeding of IRRDB Symposium (pp. $276-280)$. H a in an, $\mathrm{Ch}$ ina: International Rubber Research and Development Board (IRRDB).

Breton, F., Sanier, C., \& D'Auzac, J. (2000). Role of cassiicolin, a host-selective toxin, in pathogenicity of Corynespora cassiicola, causal agent of leaf fall disease on Hevea. Journal of Rubber Research, 3(2), 115-128.

Déon, M., Bourré, Y., Gimenez, S., Berger, A., Bieysse, D., de Lamotte, F., Poncet, J., Roussel, V., Bonnot, F., Oliver, G., Franchel, J., Sequin, M., Leroy, T., Roeckel-Drevet, P., \& Pujade-Renaud, V. (2012). Characterization of a cassiicolin-encoding gene from corynespora cassiicola, pathogen of rubber tree (Hevea brasiliensis). Journal of Plant Science, 185-186, 227237 . D o i 10.1016/j.plantsci.2011.10.017

Fernando, T.H.P.S., Jayasinghe, C.K., Wijesundera, R.L.C., Silva, W.P.K., \& Nishantha, E.A.D.N. (2010). Evaluation of screening methods against Corynespora leaf fall disease of rubber (Hevea brasiliensis). Journal of Plant Diseases and Protection, 117(1), 24-29. Doi : 10.1007 / BF03356329

Hadi, H., Hartana, A., \& Sinaga, M. (2004). Analisis genetika pewarisan sifat ketahanan tanaman karet terhadap penyakit gugur daun Corynespora. Hayati, 11(1), 1-5.

Jayasinghe, C.K. (2000). Corynespora leaf fall: The most challenging rubber disease in Asian and African Continents. Bulletin of the Rubber Research Institute of Sri Lanka, 42, 5664.

Jayasinghe, C.K., \& Fernando, T.H.P.S. (2011). Corynespora Leaf Fall of Hevea Rubber The Most Threatening Leaf Disease in Asia \& African Continents. Colombo, Srilanka : Common Fund for Commodities (CFC) \& International Rubber Research and Development Board (IRRDB).
Kusdiana, A.P.J., \& Oktavia, F. (2014). Resistensi plasma nutfah IRRDB 1981 terhadap penyakit gugur daun Corynespora. Widyariset, 17(2), 175$182 . \quad$ D o i 10.14203/widyariset.17.2.2014.175181.

Kusdiana, A.P.J., \& Syafaah, A. (2015). Pengujian resistensi klon rekomendasi tanaman karet terhadap penyakit gugur daun Corynespora. Prosiding Dies Natalis Fakultas Pertanian UNSRI ke-52 tahun 2015 (pp. 693-701). Palembang, Indonesia: Fakultas Pertanian, Universitas Sriwijaya.

Manju, M.J., Benagi, V.I., Shankarappa, T.H., Vinod, K.K., \& Jacob, C.K. (2015). Major disease of Hevea brasiliensis in rubber growing regions of South India. Environment \& Ecology, 33(3A), 1299 1302.

aktavia, F., Sudarsono, Kuswanhadi., Dinarty, D., \& Widodo. (2016). Identifikasi ketahanan plasma nutfah karet IRRDB 1981 terpilih terhadap penyakit gugur daun Corynespora berdasarkan aktivitas toksin cassiicolin. Jurnal Penelitian Karet, $34(1), 35-48$. D O I : 10.22302/ppk.jpk.v34i1.225

'oktavia, F., Kuswanhadi., Sudarsono, Dinarti, D., \& Widodo. (2016). Diversity analysis of Corynespora cassiicola isolated from Indonesian Rubber Research Plantations. Proceedings of the International Rubber Conference 2016 (pp. 468-480). Siem Reap, Cambodia: International Rubber Research and Development Board (IRRDB) and Cambodian Rubber Research Institute (CRRI).

Pawirosoemardjo, S. (2004). Manajemen pengendalian penyakit penting dalam upaya mengamankan target produksi karet nasional tahun 2020. Prosiding Pertemuan Teknis Strategi Pengelolaan Penyakit Tanaman Karet Untuk Mempertahankan Potensi Produksi Mendukung Industri Perkaretan Indonesia Tahun 2020 (pp. 21-45). Palembang, Indonesia: Balai Penelitian Sembawa, Pusat Penelitian Karet. 
Sinaga, M.S. (2006). Dasar-dasar ilmu penyakit tumbuhan. Jakarta, Indonesia: Penebar Swadaya.

Situmorang, A., Suryaningtyas, H., Pawirosoemardjo, S., \& Sinaga, M.S. (2000). The development and virulence of races of Corynespora cassiicola on the rubber plant. Indonesian Rubber conference and IRRDB Symposium (pp. 225-234). Bogor, Indonesia: Indonesian Rubber Research Institute.

Situmorang, A. (2002). Sebaran penyakit gugur daun, virulensi dan genetika Corynespora cassiicola asal sentra perkebunan karet Indonesia (Disertasi), Institut Pertanian Bogor, Indonesia.

Situmorang, A., Sinaga, M.S., Suseno, R., Hidayat, S.H., Siswanto, \& Darussamin, A. (2004). Status dan manajemen pengendalian penyakit gugur daun Corynespora di perkebunan karet. Prosiding Pertemuan Teknis Strategi Pengelolaan Penyakit Tanaman Karet untuk Mempertahankan Potensi Produksi Mendukung Industri Perkaretan Indonesia Tahun 2020 (pp. 97-118). Palembang, Indonesia: Balai Penelitian Sembawa, Pusat Penelitian Karet.
Situmorang, A., Sinaga, M.S., Suseno, R., Hidayat, S.H., Siswanto., \& Darussamin, A. (2007). Virulensi isolat Corynespora cassiicola asal sentra perkebunan karet Indonesia terhadap beberapa klon karet anjuran. Jurnal Penelitian Karet, 25 (2), 37-58.

Suryaningtyas, H. (2012). Pengendalian penyakit. Dalam M. Lasminingsih, H. Suryaningtyas, C. Nancy, \& A. Vachlepi (Ed.). Saptabina Usaha Tani Karet Rakyat (pp. 67-79). Palembang, Indonesia: Balai Penelitian Sembawa.

Tan, A., \& Tan, A. M. (1996). Genetic studies of leaf diseases resistance in Hevea. Journal of Natural Rubber Research, $11(2), 108-114$.

Woelan, S., Sayurandi, \& Pasaribu, S.A. (2012). Keragaan klon IRR seri 300 dan 400 di pengujian plot promosi. Warta Perkaretan, 31(1), 1-9. Doi : 10.22302/ppk.wp.v31i1.261 